\title{
POLLINATORS OF PULSATILLA GRANDIS WENDER. IN SOUTHERN BAKONY (HUNGARY)
}

\author{
MÉSZÁROS, T. ${ }^{*}-$ JÓZAN, Zs. $^{2}$ \\ ${ }^{I}$ Department of Plant Sciences and Biotechnology, Georgikon Faculty, University of Pannonia \\ Keszthely, Festetics u. 7, 8360 Hungary \\ (phone: +36-83-545-095; fax +36-83-545-058) \\ ${ }^{2}$ Mernye, Rákóczi Ferenc u. 5, 7453 Hungary \\ *Corresponding author \\ e-mail:meszarost773@gmail.com \\ (Received $23^{\text {rd }}$ Jul 2018; accepted $5^{\text {th }}$ Oct 2018)
}

\begin{abstract}
Sexual reproduction plays an important role in the maintenance of the genetic variability of plant species. In the case of entomophilous species (like Pulsatilla grandis) pollinators are needed to this way of propagation. It is important to have complete knowledge on the pollinators to understand the biology of plant species. Our aim was to collect information about the pollinators of $P$. grandis, as there is no available data on the pollinators of this endangered species. We studied the flower-visiting species in 2017 and 2018 on the Csatár Hill near Veszprém (Hungary) in a population of about 2000 individuals of $P$. grandis. The number of collected Apis mellifera individuals (239) was the highest followed by Bombus (31 individuals) and Andrena (15 individuals) species. Lasioglossum, Polistes and Priocnemis species were collected as well. We collected 5 male insects which visit the flowers only for nectar but they can help the self-pollination as they are searching for nectar in the flower. We recorded the most intense flower visitation between 10-11 a.m. Our new results can help to develop the conservation strategy of $P$. grandis.
\end{abstract}

Keywords: flower-visiting insects, Apis mellifera, Bombus, pollen, nectar

\section{Introduction}

The frequency and intensity of grazing is decreasing due to the decline in livestock farming. As a result the diversity of semi-natural grasslands is decreasing as well. The species number of plants and insects is dwindling in these habitats (Walker and Pinches, 2011). Biodiversity influences ecosystem services in some semi-natural landscapes (Lowenstein et al., 2015). Having enough information about the pollination strategy of rare and endangered species is a key factor to develop protection and management strategies. However, our knowledge is imperfect even in the case of intensively studied species (Denisow et al., 2014a; Gostin, 2011). In the case of metapopulations it is especially important to know the plant-pollinator interactions and the requirements of effective gene flow to maintain healthy populations of rare and endangered species (Schemske et al., 1994). Sexual reproduction is essential from genetic and evolutional aspects. It contributes to the inter- and intrapopulation genetic variability of individuals (Charlesworth and Charlesworth, 1987). Fructification rate and seed set depends on fertilization which is the result of pollination, so the effectiveness of pollination is a key factor in the reproduction success of entomophilous species (Larson and Barrett, 2000). The plant-pollinator interactions are very complex and can be influenced by many factors in addition to environmental ones (Denisow et al., 2014a). In the temperate climate zone about $80 \%$ of plant species is pollinated by insects. Both cultivated and wild species are important elements of pollination systems (Strzałkowska et al., 2016). In 
the case of early spring flowering species the number of pollinators is low. The number of flower-visitations by insects is limited due to unfavourable weather conditions (Kratochwil, 1988). In early spring pollen is an especially important protein source for insects (Moquet et al., 2015). The demand for nectar and pollen increases quickly in early spring by bee-like insects (Denisow, 2006). The pollen is needed to forage the brood to reach the proper family size. Pulsatilla grandis is a valuable and threatened species of semi-dry grasslands. This species is a significant pollen source for bees as it is flowering in early spring. The morphology and ecology of Pulsatilla species also promote the pollination by insects (Zimmermann, 1935). They attract insects with their bell-shaped, actinomorphic flowers and lots of yellow stamens (Walker and Pinches, 2011; Essl, 2005). In the case of partly opened flowers the pollinators first touch the pistils so they can be fertilized with the pollen carried from another plant. While in the case of older, fully opened flowers the bees land on tepals, so they first touch the stamens and after that the pistils (Zimmermann, 1935). Some authors classified Pulsatilla species as pollen producing plants, having a lot of stamens but producing no nectar, similar to other species of the Ranunculaceae family. Although WeryszkoChmielewska and Sulborska (2011) proved that the staminodes of Pulsatilla flowers produce nectars, so they function as nectaries. Staminodes are much smaller than stamens and have a simple structure. They can be found on the basis of the androecium. The nectar is produced when the pistil is ready for fertilization. Insects have to reach the basis of androecium to reach the nectar. Meanwhile they support fertilization as they touch the stigma. The pollen production of Pulsatilla species is $4.22-9.16 \mathrm{~g} / \mathrm{m}^{2}$, so they are significant pollen sources. These species produce more pollen than other early spring perennials (Strzałkowska-Abramek et al., 2016). Pulsatilla grandis has different strategies to ensure the efficient pollination. It can close its flowers in the case of unfavourable weather conditions (rain, wind) until the flowers are not pollinated (Sauberer and Panrok, 2015). Most anthers of Pulsatilla flowers open in the warmest hours of the day, which is typical of many other early spring species as well (Denisow et al., 2014b, 2015). Pollen emission round midday is advantageous for early spring plants and increases the number of insect visitations (Strzałkowska et al., 2016). The anthers open one after the other. So the flower produces pollen during a long period of time and the ratio of fertilization is higher. This long period of pollen emission is important from population genetic aspect. The number of pollinators, carrying pollen from other individuals, increases as well, so the genetic variability of the next generation multiplies (Kratochwil, 1988). Because the flying distance of pollinator insects is about $10 \mathrm{~km}$, the gene flow between distant populations is not probable (Walker, 2011). Pulsatilla vulgaris Mill. is a related species occurring in Western Europe. The success of its reproduction is considerably influenced by the pollination of insects and the spread of pollen depends on the flying distance of pollinators. There is a positive correlation between the foraging distance and the size of pollinator species. Bumblebee species which also visit its flowers has longer foraging range and provide gene flow between distant populations as well (Hensen et al., 2005; Walther-Hellwig and Frank1, 2000; Osborne et al., 2008). It was observed that besides bumblebees honey bees have longer flying distances as well (Steffan-Dewenter and Kuhn, 2003), therefore these insects have significant role in the pollination of populations living in fragmented habitats.

Insects visit Pulsatilla species both for nectar and pollen (Table 1). However, the visiting Apoidea species do not fertilize the flowers in every cases, some of them are nectar robbers (Kratochwil, 1988). 
Our aim was the collect information about the pollinators of $P$. grandis, as there is no available data on the pollinators of this endangered species.

Table 1. Pollinators of the Pulsatilla genus and Pulsatilla vulgaris

\begin{tabular}{|c|c|c|c|}
\hline Taxon & Pollinator & Comment & Reference \\
\hline Pulsatilla genus & $\begin{array}{c}\text { Apis mellifera } \\
\text { Linnaeus, } 1758 \\
\text { Bombus terrestris } \\
\text { (Linnaeus, 1758) }\end{array}$ & $\begin{array}{l}\text { Mainly visited by } \\
\text { honey bees (Apis } \\
\text { mellifera Linnaeus, } \\
\text { 1758) for pollen and } \\
\text { nectar }\end{array}$ & Zimmermann (1935) \\
\hline Pulsatilla genus & $\begin{array}{c}\text { Honey bees and bumble } \\
\text { bee species }\end{array}$ & $\begin{array}{l}\text { Pollen and nectar } \\
\text { collection }\end{array}$ & $\begin{array}{c}\text { Weryszko-Chmielewska and } \\
\text { Sulborska (2011) }\end{array}$ \\
\hline P. vulgaris & & Nectar collecting bees & $\begin{array}{c}\text { Weryszko-Chmielewska and } \\
\text { Sulborska (2011) }\end{array}$ \\
\hline P. vulgaris & $\begin{array}{c}\text { Lasioglossum lineare } \\
\text { (Schenck, 1869), } \\
\text { Andrena bicolor } \\
\text { Fabricius, } 1775\end{array}$ & $\begin{array}{l}\text { Solitary bees are the } \\
\text { main pollinators }\end{array}$ & Kratochwil (1988) \\
\hline P. vulgaris & $\begin{array}{l}\text { Halictidae family, } \\
\text { Andrena genus }\end{array}$ & & Sauberer and Panrok (2015) \\
\hline P. vulgaris & $\begin{array}{l}\text { Apis and Bombus } \\
\text { species }\end{array}$ & & $\begin{array}{c}\text { Walker (2011), } \\
\text { Walker and Pinches (2011) }\end{array}$ \\
\hline P. vulgaris & $\begin{array}{c}\text { Halictus fulvicornis } \\
\text { (Kirby, 1802), H. } \\
\text { tumulorum (L.1758), H. } \\
\text { albipes (Fab. 1781), H. } \\
\text { flavipes (Fab. 1787), H. } \\
\text { leucopus (Kirby, 1802), } \\
\text { Osmia bicolor } \\
\text { (Schrank, 1781), and } \\
\text { Bombus agrorum (Fab. } \\
\text { 1787) [=B. pascuorum } \\
\text { (Scopoli, 1763)] }\end{array}$ & Great Britain & Wells and Barling (1971) \\
\hline
\end{tabular}

\section{Materials and methods}

\section{Study species}

Pulsatilla grandis Wender. is a Natura 2000 species, wich is listed in the Annex II and Annex IV of the Habitats Directive of the European Commission (Council Directive 92/43/EEC) (Randic et al., 2013). Its range is Pannonian type, i.e. distributed from Western Ukraine to Austria and the Czech Republic (Sauberer and Panrok, 2015). It is listed as a threatened species, e.g. in Germany, Czech Republic, Slovenia, Slovakia and Ukraine (Dostalova and Király, 2013).

This perennial species of dry grasslands is flowering in early spring. Its attractive flowers are pollinated by insects.

Its flowers open in late February or early March. The leaves develop at the end of flowering. After flowering the peduncle elongates bearing the fruit over the layer of other plants which helps the dispersion of seeds by wind (Kaligaric et al., 2006; Sauberer and Panrok, 2015). 
Flowers are mainly cross-pollinated but in the lack of allogamy self-pollination is also possible (Walker and Pinches, 2011; Zimmermann, 1935; Lindell, 1998).

\section{Study area}

The pollinators of $P$. grandis were studied on the calcareous rocky steppes of the Csatár Hill (N47.107830, E17.848507) (Figs. 1, 2 and 3), near Veszprém in Southern Bakony (Hungary). The summit of this dolomite hill is 340 metres above sea level. This population of $P$. grandis contains more thousand individuals. The botanical values of the area are threatened by the expansion of weekend houses.

\section{Measuring pollinators}

The pollinators were studied in the spring of 2017 and 2018. The methods were different in the two years. On the 25 March 2017 we observed three fully-opened flowers of an individual and one fully-opened flower of another one. On the 28th March 2017 three fully-opened flowers of an individual were studied (no other flower visitation was recorded). The flower-visitations were recorded through $18 \mathrm{~h}$ from between 9 a.m. and 5 p.m. on both days. The weather was sunny and windless on both days.

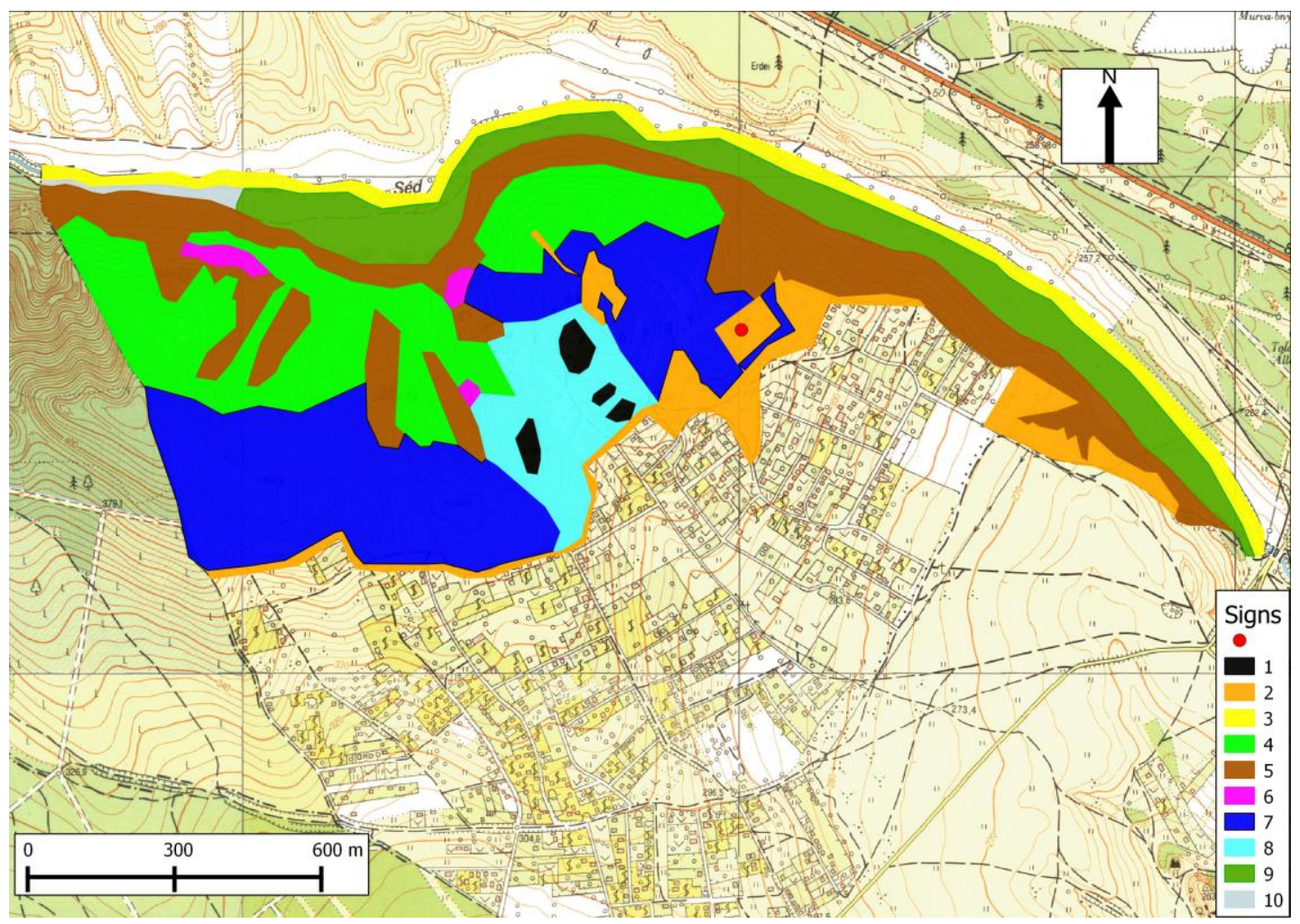

Figure 1. Vegetation map of the Csatár Hill (vegetation types were classified according to Borhidi (2003)). Legend: red point: experimental site, 1: Seselio leucospermi-Festucetum pallentis Zólyomi (1936) 1958, 2: Chrysopogono-Caricetum humilis Zólyomi (1950) 1958, 3: Aegopodio-Alnetum V. Kárpáti, I. Kárpáti \& Jurko 1961, 4: Mercuriali-Tilietum Zólyomi \& Jakucs in Zólyomi 1958, 5: Daphno laureolae-Fagetum (Isépy 1970) Borhidi in Borhidi \&

Kevey 1996, 6: Fago ornetum Zólyomi (1950) 1958, 7: Vicio sparsiflorae-Quercetum pubescentis Zólyomi ex Borhidi et Kevey 1996, 8: Cotino-Quercetum pubescentis Soó (1931) 1932, 9: Arvum et ager incultum, 10: Urtico-Convolvuletum Görs \& T. Müll. 1969 


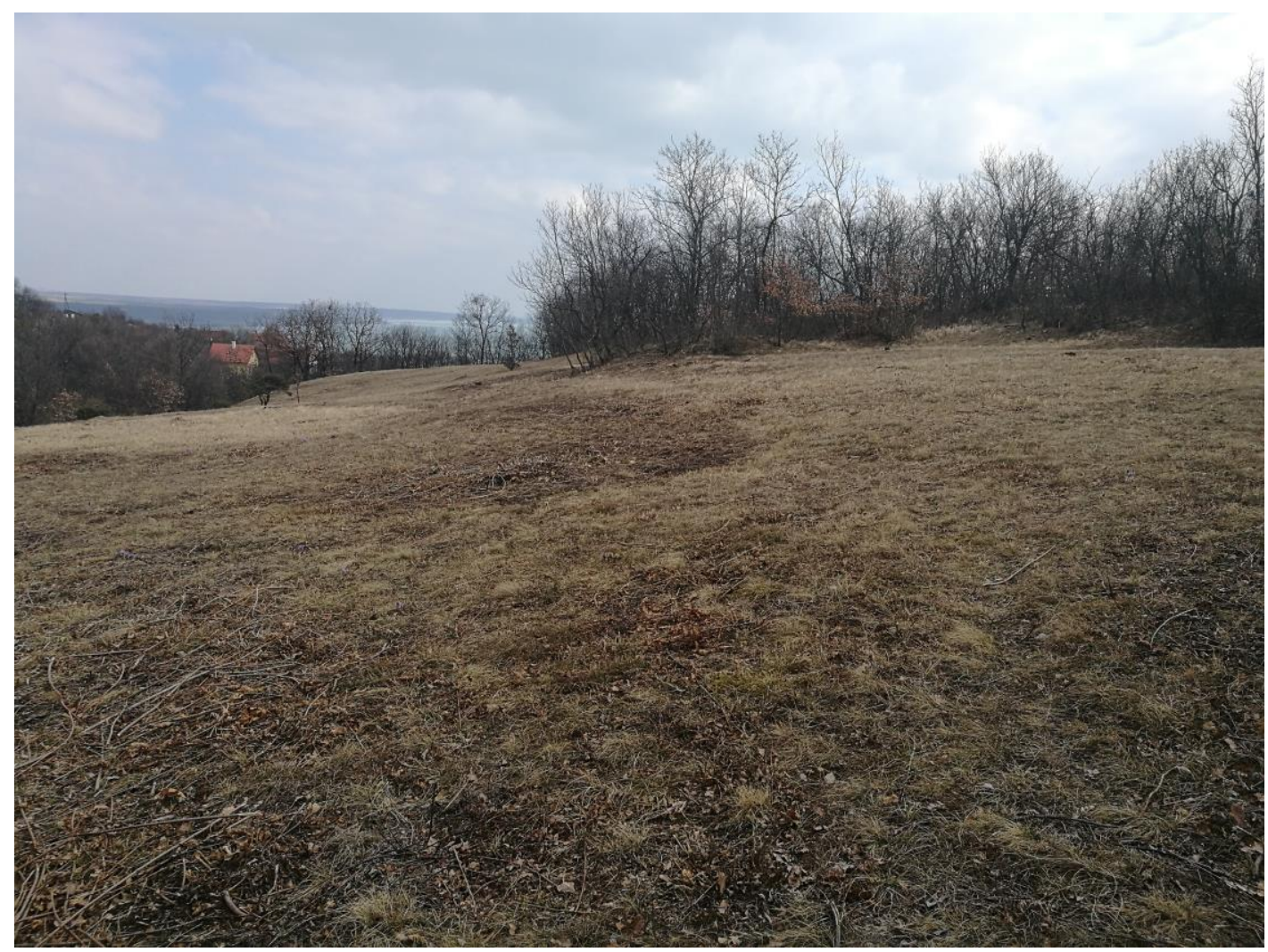

Figure 2. Experimental site. (Photo: T. Mészáros, date: 11.03.2017)

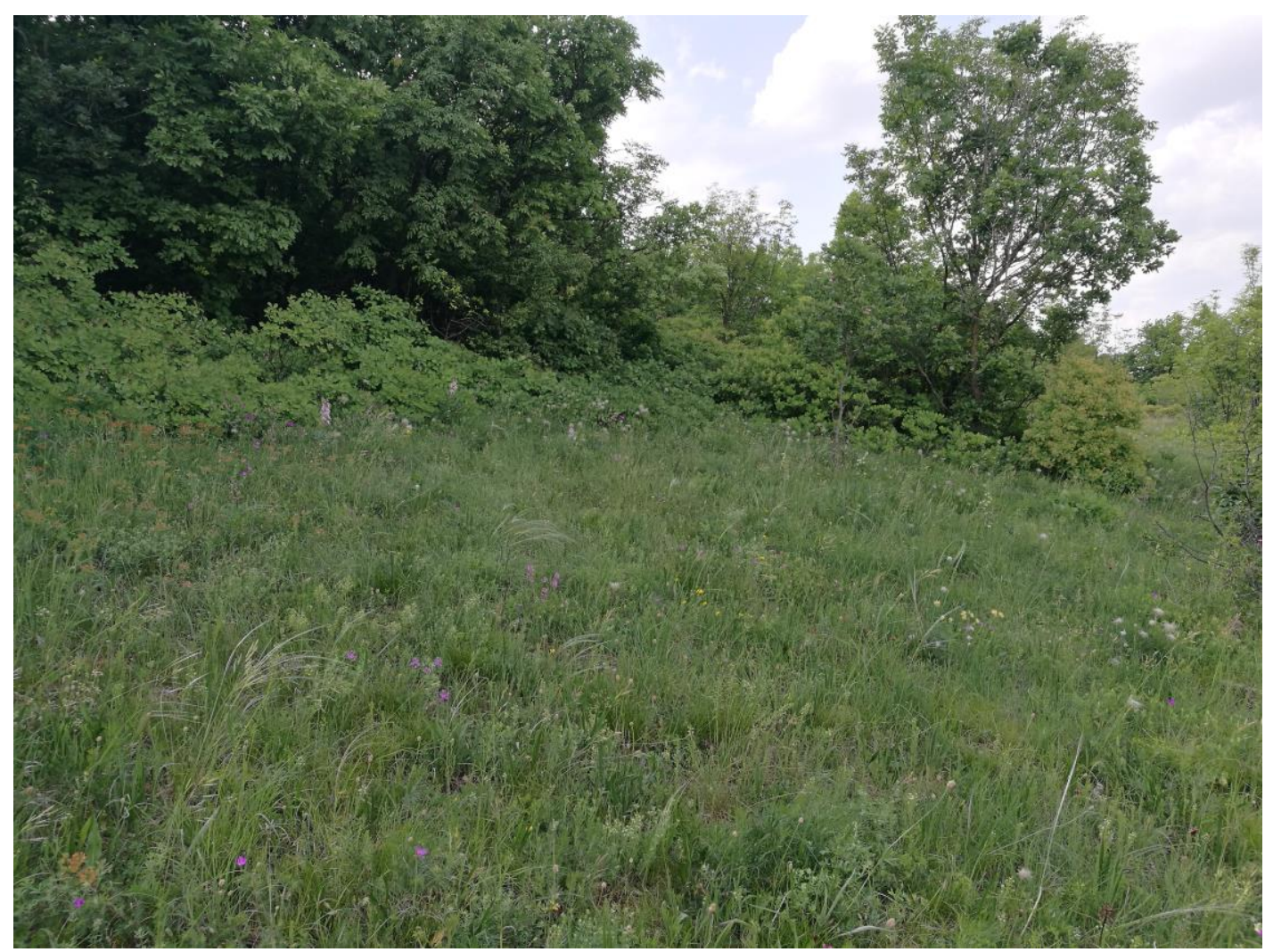

Figure 3. Experimental site. (Photo: T. Mészáros, date: 10.05.2018)

APPLIED ECOLOGY AND ENVIRONMENTAL RESEARCH 16(5):7045-7062. http://www.aloki.hu • ISSN 15891623 (Print) • ISSN 17850037 (Online) DOI: http://dx.doi.org/10.15666/aeer/1605_70457062 (c) 2018, ALÖKI Kft., Budapest, Hungary 
Photos were taken about the flower visiting insects to identify them and record the time of visitation. With this method it was possible for pollinators to visit the flowers more times. However this method was not effective enough. Only a little ratio of visitations was recorded and identified. At the same time only these results show that some pollinators visit the same plant individuals repeatedly. Those individuals that were not identified reliably are not included in the results of this study. In 2018 we studied a 3800 square metres area. The number of $P$. grandis individuals was about 2600 . The pollinators were collected in glasses every hour. An insect collecting nest $(30 \mathrm{~cm}$ in diameter) was used to collect the insects individually and then put them in the glasses. We studied the area through $20 \mathrm{~h}$ on 2-10 April (1-3 people collected simultaneously). The length of observation $(25 \mathrm{~h})$ and sampling $(20 \mathrm{~h})$ were different as there were periods when no pollinators visited the plants (Table 2). The study days were sunny and windless, excepting 4 April which was a sunny but very windy day. The individuals were identified with a binocular microscope by Zs. Józan. The collected individuals were identified according to following literature: Andrenidae species: Schmid-Egger and Scheuckl (1977), Apis mellifera and Bombus species: Móczár (1957), Halictidae species: Móczár (1967) and Ebmer (1970), Osmia species: Móczár (1958), Vespidae species: Móczár (1995), Pompilidae species: Wolf (1972) and for all species: Schmiedeknecht (1930).

Table 2. Flower visitations of Pulsatilla grandis (2018)

\begin{tabular}{c|c|c}
\hline Date & Length of observation (h) & Length of sampling (h) \\
\hline 2 April & 3 p.m.-6 p.m. & 3 p.m.-6 p.m. \\
3 April & 9 a.m.-4 p.m. & 10 a.m.-4 p.m. \\
4 April & 9 a.m.-4 p.m. & 10 a.m.-3 p.m. \\
8 April & 9 a.m.-4 p.m. & 10 a.m.-3 p.m. \\
10 April & 11 a.m.-12 a.m. & 11 a.m.-12 a.m. \\
\hline Total: & $\mathbf{2 5}$ & $\mathbf{2 0}$ \\
\hline
\end{tabular}

a.m. $=$ before noon, p.m. $=$ after noon

Besides the cited publications distribution data of species are based on the unpublished studies of Zs. Józan who studied and collected pollinators through 5 decades in the Bakony Hills, Western and Southern Transdanubia. Flower-visitation data was collected by the author and Jenö Papp. The specimens of collected insects are preserved in the Rippl-Rónai Museum (Kaposvár, Hungary) and in the Natural History Museum of the Bakony Hills (Zirc, Hungary).

\section{Results}

In 2017 we recorded 31 flower-visitations of Aculeata (6 species) species (Table 3). Apis mellifera was the most frequent ( $80 \%$ of all visitations) pollinator of $P$. grandis. The Bombus genus was the second most frequent with $12 \%$. The flower-visitations of Andrena and Lasioglossum species were not significant, both representing 3\%.

We recorded the most visitations between 10-11 a.m., followed by the period between 11-12 a.m. Apis species visited the flowers between 9 a.m and 3 p.m., the Bombus species between 10 a.m. and 3 p.m., the Andrena species between 11-12 a.m., 
while the Lasioglossum species between 12-1 p.m. There was no visitation between 1-2 p.m.

Table 3. Aculeata pollinators of Pulsatilla grandis in decreasing frequency (2017)

\begin{tabular}{c|c|c|c}
\hline Species & Sex & $\begin{array}{c}\text { Number of flower- } \\
\text { visitations (during 18 h) }\end{array}$ & $\begin{array}{c}\text { Time of flower } \\
\text { visitation }\end{array}$ \\
\hline Apis mellifera Linnaeus, 1758 & Worker & 25 & 9 a.m.-1 p.m., 2-3 pm. \\
Bombus lapidarius (Linnaeus, 1758) & + & 2 & $11-12$ a.m., 2-3 p.m. \\
Bombus pascuorum (Scopoli, 1763) & + & 1 & $10-11$ a.m. \\
Andrena bicolor (Fabricius, 1775) & + & 1 & $11-12$ a.m. \\
Lasioglossum fulvicorne (Kirby, 1802) & + & 1 & $12-1$ p.m. \\
Bombus haematurus (Kriechbaumer, 1870) & + & 1 & $12-1$ p.m. \\
\hline Total: & & $\mathbf{3 1}$ & \\
\hline
\end{tabular}

+ = female, a.m. $=$ before noon, p.m. $=$ after noon

In 201823 species (299 individuals) were collected (Table 4). Apis mellifera was the most frequent ( $80 \%$ of all visitations) pollinator of $P$. grandis. It was followed by the Bombus genus with $10 \%$. The ratio of Andrena species was only 5\% (Table 5).

Table 4. Aculeata pollinators of Pulsatilla grandis in decreasing frequency (2018)

\begin{tabular}{|c|c|c|c|}
\hline Species & \begin{tabular}{|l|} 
Number of \\
individuals
\end{tabular} & Sex & Time of flower visitation \\
\hline Apis mellifera (Linnaeus, 1758) & 239 & Worker & 10 a.m.-6 p.m. \\
\hline Bombus lapidarius (Linnaeus, 1758) & 8 & q & 11 a.m.-1 p.m., 2-3 pm. \\
\hline Andrena bicolor (Fabricius, 1775) & 6 & $5 q+1$ ठ & 10-11 a.m., $12-2$ p.m. \\
\hline Bombus pratorum (Linnaeus, 1761) & 6 & q & $12-5$ p.m. \\
\hline Bombus haematurus (Kriechbaumer, 1870) & 5 & q & 10-12 a.m., 3-4 p.m., 5-6 p.m. \\
\hline Bombus hypnorum (Linnaeus, 1758) & 5 & 우 & 10-11 a.m., $12-2$ p.m. \\
\hline Osmia cornuta (Latreille, 1805) & 5 & 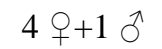 & $12-2$ p.m. \\
\hline Bombus terrestris (Linnaeus, 1758) & 4 & 우 & 10 a.m.-2 p.m. \\
\hline Andrena gravida (Imhoff, 1832) & 3 & $2++10^{\pi}$ & 12-2 p.m., 3-4 p.m. \\
\hline Bombus pascuorum (Scopoli, 1763) & 2 & q & 11-12 a.m., 1-2 p.m. \\
\hline Lasioglossum laterale (Brullé, 1832) & 2 & q & 11 a.m-1 p.m. \\
\hline Osmia bicolor (Schrank, 1781) & 2 & q & $12-12$ p.m. \\
\hline Polistes nimpha (Christ, 1791) & 2 & 우 & 12-1 p.m. \\
\hline Andrena bimaculata (Kirby, 1802) & 1 & 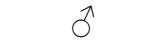 & 2-3 p.m. \\
\hline Andrena bluethgeni (Stöckhert, 1930) & 1 & o & 11-12 a.m. \\
\hline Andrena dorsata (Kirby, 1802) & 1 & 우 & $11-12$ a.m. \\
\hline Andrena jacobi (Perkins, 1921) & 1 & $0^{2}$ & 4-5 p.m. \\
\hline Andrena nitida (Müller, 1776) & 1 & q & 12-1 p.m. \\
\hline Andrena vaga (Panzer, 1799) & 1 & 우 & 1-2 p.m. \\
\hline Bombus ruderarius (Müller, 1776) & 1 & 우 & 12-1 p.m. \\
\hline Lasioglossum bluethgeni (Ebmer, 1971) & 1 & 우 & 2-3 p.m. \\
\hline Lasioglossum xanthopus (Kirby, 1802) & 1 & 우 & 11-12 a.m. \\
\hline Priocnemis mimula (Wesmael, 1851) & 1 & 우 & 2-3 p.m. \\
\hline Total: & 299 & & 10 a.m -6 p.m. \\
\hline
\end{tabular}

$q=$ female, ${ }^{\lambda}=$ male, a.m. $=$ before noon, p.m. $=$ after noon 
Table 5. Aculeata pollinators (genus) of Pulsatilla grandis in decreasing frequency (2018)

\begin{tabular}{c|c|c}
\hline Genus & Number of individuals & Ratio of all flower visits (\%) \\
\hline Apis & 239 & 79.9 \\
Bombus & 31 & 10.4 \\
Andrena & 15 & 5.0 \\
Osmia & 7 & 2.3 \\
Lasioglossum & 4 & 1.3 \\
Polistes & 2 & 0.7 \\
Priocnemis & 1 & 0.3 \\
\hline Total: & $\mathbf{2 9 9}$ & $\mathbf{1 0 0}$ \\
\hline
\end{tabular}

We observed the most flower-visitation between 10-11 a.m., followed by the period between 12-1 p.m. (Table 6). Apis and Bombus species visited the flowers between 10 a.m. and 6 p.m., while Andrena species between 10 a.m. and 5 p.m.

Table 6. Temporal distribution of Pulsatilla grandis pollinators (2018, daylight saving time)

\begin{tabular}{c|c|c}
\hline Time & Number/hour & Ratio (\%) \\
\hline 10-11 a.m. & 66 & 22.0 \\
11-12 a.m. & 55 & 18.4 \\
12-1 p.m. & 60 & 20.1 \\
1-2 p.m. & 40 & 13.4 \\
2-3 p.m. & 25 & 8.4 \\
3-4 p.m. & 16 & 5.3 \\
4-5 p.m. & 26 & 8.7 \\
5-6 p.m. & 11 & 3.7 \\
\hline Total: & $\mathbf{2 9 9}$ & $\mathbf{1 0 0}$ \\
\hline
\end{tabular}

a.m. $=$ before noon, $\mathrm{p} . \mathrm{m} .=$ after noon

We collected the most number of insects (34 individuals) on 8 April between 10-11 a.m., while we collected the fewest (1 individual) on 10 April between 10-11 a.m. There was no visitation before 10 a.m. We recorded visitations between 4-6 p.m. only on the first few days. Later no visitation was observed after 4 p.m.

We found 5 males besides the females and workers (Andrena bicolor, A. gravida, A. bimaculata, A. jacobi, Osmia cornuta).

Three quarters of bee-like species collected from $P$. grandis have a wide range (Palearctic, Western Palearctic and Eurosiberian). One quarter of the species occurs in certain regions of Europe, and only $15 \%$ lives in the Mediterranean with a range extending to Central Europe.

The ratio of species preferring warm habitats (eremophil) was only $20 \%$. The species of cool and wet habitats represented 35\%. Most of the species (45\%) are eurytopic.

The species are polilectic, except Andrean vaga which is an oligolectic species. According to the studies of Zs. Józan in the Bakony Hills, Western and Sothern Transdanubia $45 \%$ of species visited less than 25 plant species, 30\% visited $26-50$ species, $10 \%$ visited $51-75$ species, while $15 \%$ visited more than 76 plant species for pollen or nectar. 


\section{Collected species}

\section{Apidae}

Apis mellifera Linnaeus, 1758

It was the most dominant pollinator species. Our only social bee species that has perennial colonies. It is a eurytopic species (Móczár, 1957), its subspecies can be found worldwide (Móczár, 1957). The workers visit practically the flowers of every plant species that produce pollen or nectar (unpublished data of the author). In early spring they visit the catkins of Salix species (Salix caprea, Salix cinerea) which produce a high amount of pollen. $P$. grandis seems to be a good source of pollen and nectar as well. The pollen baskets of specimens collected from its flowers were full of pollen. After winter the workers feed the first larvae generation with this protein rich forage. From the end of March they start to visit the flowers of fruit trees, so the visitation of other plants become less significant. It has economic and ecological significance (Rand et al., 2015).

\section{Bombus haematurus Kriechbaumer, 1870}

This bumblebee species has Ponto-Mediterranean range (Móczár, 1957). Its number has been increasing rapidly in Hungary in the last decades. The species was first observed in Hungary in 1990 in the Mecsek Hills. Later about 40 occurrences have been recorded in the Bakony Hills, Transdanubian Hills, Mecsek Hills, Villányi Hills, furthermore in Vas County and near Bösárkány (North Hungary) (Józan, 1995, 1996b, 1998, 2000a, 2003, 2006, 2009, 2016, 2017). Sárospataki et al. (2004) classified the species as rare and highly threatened. However, the studies of recent years show it is not so rare. It is also supported by the fact that the species was observed together with other common species on the Csatár Hill. Visited plant species: Rubus idaeus, R. fruticosa, Geum urbanum (Rosaceae), Vicia grandiflora (Fabaceae), Galeobdolon luteum, Lamium purpureum, L. maculatum (Labiatae), Symphytum officinale (Boraginaceae), Corydalis cava, Lonicera sp., Philadelphus coronarius (other plant families) (Józan, 2009, 2017).

\section{Bombus hypnorum (Linnaeus, 1758)}

B. hypnorum is a Eurosiberian bumblebee which prefers habitats with cool and humid microclimate (Móczár, 1953, 1957). It is moderately rare in Hungary (Móczár, 1953; Sárospataki et al., 2004). The species has been observed in 30 localities in Hungary from Bösárkány through the Bakony Hills, the Transdanubian Hills, the Mecsek Hills until the Villányi Hills (Józan, 1990, 1992a, 1995, 1996a, 1998, 2000a, 2000b, 2001, 2006, 2016, 2017). Visited plant species: Rubus idaeus, Rosa sp. (Rosaceae), Lamium maculatum (Labiatae), Calendula officinalis, Cirsium arvense (Asteraceae), Anchusa officinalis, Echium vulgare (Boraginaceae), and Berberis vulgare, Epilobium montanum, Knautia drymeia, Lycium barbarum, Salix cinerea, Symphoricarpus albus, Philadelphus coronarius (other plant families) (Józan, 2017).

\section{Bombus lapidarius (Linnaeus, 1758)}

It is a common eurytopic species living in the Western-Palearctic range (Móczár, 1953, 1957; Sárospataki et al., 2004). It is common everywhere in Hungary. It has been found in lots of localities during our studies (Józan, 1985, 1992a, 1992b, 1995, 1996a, 1996b, 1998, 2000a, 2000b, 2001, 2002, 2003, 2006, 2009, 2016, 2017). Its pollination 
was recorded on 50 plant species of 23 plant families. Most of the species belong to the Fabaceae, Labiatae and Asteraceae families (Józan, 2009, 2016, 2017).

Bombus pascuorum (Scopoli, 1763)

It is a eurytopic Eurosiberian bumblebee species (Móczár, 1953, 1957; Sárospataki et al., 2004). B. pascuorum is the most common bumblebee species in Hungary according to our studies (Józan, 1990, 1992a, 1992b, 1995, 1996a, 1998, 2000a, 2000b, 2001, 2006, 2009, 2014, 2016, 2017). It has been collected from 70 plant species of 22 plant families (Józan, 2009, 2016, 2017).

Bombus pratorum (Linnaeus, 1761)

$B$. pratorum lives in habitats with cool and humid microclimate. Its range is of Eurosiberian type (Móczár, 1953, 1957). B. pratorum was classified as moderately rare in Hungary (Sárospataki et al., 2004). During our faunistic studies it has been collected from 40 localities in Transdanubia (Józan, 1990, 1992a, 1996a, 2000b, 2001, 2002, 2006, 2017). Visited plant species: Rubus idaeus (Rosaceae), Astragalus onobrychis, Trifolium pratense (Fabaceae), Aegopodium podagraria, Anthriscus sylvestris (Apiaceae), Ajuga reptans, Galeobdolon luteum, Marrubium peregrinum, Salvia nemorosa (Labiatae), Centaurea jacea, C. micranthos, Taraxacum officinale (Asteraceae), Stellaria sp. (Caryophyllaceae), Echium vulgare, Pulmonaria officinalis, Symphytum officinale, S. tuberosum (Boraginaceae), other plant families: Allium ursinum, Berberis vulgaris, Cerinthe minor, Geranium sp., Knautia arvensis, K.. drymeia, Melampyrum nemorosum, Ribes rubrum, Solanum nigrum, Symphoricarpus albus (Józan, 2017).

\section{Bombus ruderarius (Müller, 1776)}

It is a eurytopic bumble bee species with a Western Palearctic range (Móczár, 1957). It is moderately common in Hungary (Móczár, 1953; Sárospataki et al., 2004). We have found this species in many different localities during our faunistic studies (Józan, 1990, 1992a, 1992b, 1995, 1996a, 1996b, 1998, 2000a, 2000b, 2001, 2002, 2006, 2009, 2016, 2017). It has been collected from more than 40 species of 14 plant families (Józan, 2009, 2017).

Bombus terrestris (Linnaeus, 1758)

It is a eurytopic bumble bee species that occurs in the Palearctic region (Móczár, 1957). It is very common in every part of Hungary (Józan, 2001; Móczár, 1953; Sárospataki et al., 2004). It has been collected from 110 localities (Józan, 1985, 1990, 1992a, 1992b, 1995, 1996a, 1996b, 1998, 2000a, 2000b, 2001, 2002, 2003, 2006, 2009, 2014, 2015, 2016, 2017). Its pollination has been observed on nearly 100 species of 35 plant families. Most significant families were the Fabaceae, Labiatae and Asteraceae (Józan, 2009, 2016, 2017).

\section{Andrenidae}

\section{Andrena bicolor Fabricius, 1775}

This Eastern Palearctic mining bee species prefers cool and humid habitats (Dylewska, 1987; Móczár, 1957). A. bicolor is moderately common in Hungary (Móczár and Warncke, 1972). It has two generations per year, the first being on the wing in spring and the second in summer (Schmid-Egger and Scheuchl, 1977). It has 
been found in nearly 100 localities during our faunistic studies (Józan, 1990, 1992a, 1992b, 1996a, 1996b, 1998, 2000a, 2000b, 2001, 2002, 2003, 2006, 2009, 2014, 2016, 2017). It has been collected from 35 species of 15 plant families. The summer generation visits mainly the flowers of Campanula species (Schmid-Egger and Scheuchl, 1977; Józan, 2009, 2016, 2017).

Andrena bimaculata (Kirby, 1802)

A. bimaculata is an eurytopic mining bee species that is widespread in the Palearctic region. It has two generations per year (Dylewska, 1987; Schmid-Egger and Scheuhl, 1977). It is common in Hungary (Móczár and Warncke, 1972; Józan, 2011). It has been collected from more than 130 localities (Józan, 1985, 1990, 1992a,1992b,1995, 1996a, 1996b, 1998, 2000a, 2000b, 2001, 2003, 2009, 2014, 2016, 2017). It has been observed on 36 species of 13 plant families. The spring generation swarms mainly on the catkins of Salix species (Schmid-Egger and Scheuchl, 1977; Józan, 2009, 2016, 2017).

\section{Andrena bluethgeni Stöckhert, 1930}

The range of this species is not well-known. It has been found in Central and Northern Europe (Schmid-Egger and Scheuchl, 1977). It is very rare in Hungary. In the last century it was collected only from 4 localities near Budapest and from one locality in the North Hungarian Mountains (Móczár and Warncke, 1972). In the last decades we have observed it in six localities of the Balaton Uplands, near Esztergom, in the Zákány Hills and in Külső-Somogy (Józan, 1992a, 2000b, 2016). Visited plant species: Amygdalus communis, Cerasus vulgare, Prunus cerasifera, P. spinosa (Rosaceae), Capsella bursa-pastoris (Cruciferae), Acer platanoides (Aceraceae) (Józan, 2016).

\section{Andrena dorsata (Kirby, 1802)}

A. dorsata is a eurytopic Western Palearctic mining bee species with two generations (Dylewska, 1987). It is common in Hungary. It has been collected from more than 200 localities during our faunistic studies (Józan,1985, 1990, 1992a, 1992b, 1995, 1996a, 1996b, 1998, 2000a, 2000b, 2002, 2003, 2006, 2009, 2014, 2016, 2017). It has been noted on nearly 100 species of 27 plant families. Most of them belong to the Rosaceae, Cruciferae and Asteraceae families (Józan, 2009, 2016, 2017).

\section{Andrena gravida Imhoff, 1832}

A. gravida is a widespread mining bee species in Europe (Dylewska, 1987). Its only generation flies from early spring until May. It is common in Hungary (Móczár and Warncke, 1972). It has been found in nearly 150 localities (Józan, 1990, 1992a, 1992b, 1995, 1996a, 1996b, 1998, 2000a, 2000b, 2001, 2002, 2003, 2006, 2009, 2016, 2017). It has been collected from more than 50 species of 25 plant families. Most of them are members of the Rosaceae and Cruciferae families (Józan, 2009, 2016, 2017).

\section{Andrena jacobi Perkins, 1921}

It is a Western Palearctic species with one generation swarming in spring (Dylewska, 1987). It is moderately common in Hungary (Móczár and Warncke, 1972). We have found it in 84 localities during our studies (Józan, 1990, 1992a, 1992b, 1995, 1996a, 1996b, 1998, 2000a, 2000b, 2001, 2017) It has been collected from 24 species of 12 plant families. It has mainly visited the species of Rocaseae family (Józan, 2017). 
Andrena nitida (Müller, 1776)

A. nitida has the same range as the former species (Dylewska, 1987). Its only generation flies in the spring months. It is quite common in Hungary (Móczár and Warncke, 1972). It has been found in nearly 130 localities (Józan, 1990, 1992a, 1992b, 1995, 1996a, 1996b, 1998, 2000b, 2001, 2002, 2003, 2009, 2015, 2016, 2017). It has visited more than 50 species of 25 plant families. Most of them are members of Rosaceae and Cruciferae families (Józan, 2016, 2017).

\section{Andrena vaga Panzer, 1799}

A. vaga is a mining bee species that lives in Southern Europe (Dylewska, 1987). It flies in early spring. It is not rare in Hungary but not abundant (Móczár and Warncke, 1972). It has been collected from 60 localities in the last decades (Józan, 1985, 1990, 1992a, 1995, 1996a, 1996b, 1998, 2000b, 2001, 2003, 2006, 2015, 2016, 2017). Visited plant species: Prunus spinosa, Sorbus intermedia (Rosaceae), Lamium purpureum (Labiatae), Salix cinerea, S. rosmarinifolia (Salicaceae) (Józan, 2016, 2017).

\section{Halictidae}

Lasioglossum bluethgeni Ebmer, 1971

L. bluethgeni is a Pontomediterranean sweat bee species (Ebmer, 1988; Móczár, 1967). It has two generations. The spring generation contains only of females. It has been observed in many locations in Hungary, but it is not common. It has been collected from 35 Transdanubian localities in the last decades (Józan, 1992b, 1995, 1996a, 1998, 2000b, 2006, 2009, 2015, 2016, 2017). It has visited the flowers of the following species: Anthriscus cerefolium, A. sylvestris, Daucus carota, Pastinaca sativa (Apiaceae), Capsella bursa-pastoris, Rorippa amphibia, Lepidium draba (Cruciferae), Hieratium sp. (Asteraceae), Echium vulgare, Lithospermum purpureo-coeruleum (Boraginaceae), other families: Cotinus coggygria, Dictamnus albus, Scabiosa ochroleuca (Józan, 2009).

\section{Lasioglossum fulvicorne Kirby, 1802}

It is a eurotypic species with a Palearctic range (Ebmer, 1988; Móczár,1967). It is rare in Hungary. It has been collected only from Nagybajom (Józan, 1992a), Tótújfalu (Józan, 1995), Kővágószőlős (Józan, 1996a) and Zics (Józan, 2000b). Visited plant species: Anthemis austriaca, Berteroa incana, Capsella bursa-pastoris, Dorycnium germanicum, Ficaria verna, Orlaya grandiflora.

\section{Lasioglossum laterale (Brullé, 1832)}

This sweat bee species occurs in the Northern part of the Mediterranean (Ebmer, 1988; Móczár, 1967). It has two generations. The spring generation contains only of females. It is moderately common in Hungary (Móczár, 1967). It has been collected from more than 70 localities in the Bakony Hills and in the southern part of Transdanubia (Józan, 1990, 1992a, 1995, 1996a, 1996b, 1998, 2000a, 2000b, 2003, 2006, 2009, 2017). It has been collected from 20 species of 10 plant families.

\section{Lasioglossum xanthopus (Kirby, 1802)}

L. xanthopus is a Wester Palearctic species (Ebmer, 1988; Móczár, 1967). It also has two generations. The spring generation contains only of females. It is moderately common in Hungary (Móczár, 1967). We have found it in less localities than the former 
species (Józan, 1992a, 1995, 1998, 2000a, 2000b, 2003, 2016, 2017). According to our observations it does not occurs abundantly in any type of habitat. It has been recorded on 24 species of 13 plant families. The distribution of species was quite equal between families (Józan, 2016, 2017).

\section{Megachilidae}

\section{Osmia bicolor (Schrank, 1781)}

It is a widespread species in Europe. It swarms in spring and nests in snail shells (Móczár, 1958). It is moderately common in Hungary (Móczár, 1958). It has been collected from 75 Transdanubian localities (Józan, 1985, 1990, 1992a, 1992b, 1995, 1996a, 1996b, 1998, 2000b, 2003, 2006, 2009, 2015, 2016). It has been recorded on 22 species of 15 plant families. Most of them are member of the Rosaceae family (Józan, 2009, 2014, 2016, 2017).

\section{Osmia cornuta (Latreille, 1805)}

It is a widespread species ranging from the northern part of the Mediterranean to Central Europe. It is common in Hungary (Móczár,1958). It nests in hollow stems or other holes. The cells are separated with mud (Móczár, 1958). The males are often on wings in early March foraging on Salix catkins (author's observation). It rarely can be seen in May. It was collected from 16 species of 14 plant families. Most of them are member of the Rosaceae family (Józan, 2009, 2016, 2017).

\section{Pompilidae}

\section{Priocnemis mimula Wesmael, 1851}

It is a Palearctic pompilid species. It is distributed mainly in the hilly and mountainous regions of Hungary. It is common but not abundant (Móczár, 1956). It is a parasitoid species. It visits the flowers for nectar (Móczár, 1956). It has a limited role in pollination due to the lack of body hairs.

\section{Vespidae}

Polistes nimpha (Christ, 1791)

It is a Palearctic Vespidae species. It is very common in Hungary. First it feeds the larvae with nectar and other sweet saps. Later the larvae feed on chopped insects (Móczár, 1995). Its role in pollination is similar to the former species.

\section{Discussion}

Apis mellifera was the main pollinator of $P$. grandis in both years of our study. It was followed by Bombus species. The high number of Apis mellifera can be partly explained by the fact that an apiary can be found 300 meters from the population of $P$. grandis. The fruit trees of the Csatár Hill were not blossoming at the time of early $P$. grandis flowering, so the studied flowers were the only pollen sources for Apis mellifera. The significant role of honey bees in successful fructification was observed in the case of later flowering orchid species as well (Biró et al., 2015).

Apis and Bombus species had the longest collecting period in both years, which can be explained with the fact that both genus contains eurytopic species. 
In 2018 early spring was cold, so a large number of insects visited the flowers of Pulsatilla on 4 April even in windy weather.

In 2018 the mornings were quite cool so the flowers were not visited before 10 a.m. In the first days of our study the insects collected pollen until 6 p.m. but later their activity decreased in late afternoon which is the consequence of the long winter as well.

Males visit the flowers only for nectar. They do not have special collecting hairs, so the probability of carrying pollen from a flower to another is lower. In the lack of allogamy $P$. grandis can reproduce with self-pollination as well (Walker and Pinches, 2011; Zimmermann, 1935; Lindell, 1998). As a consequence, male insects can help the pollination of this species too. They can carry the pollen of the same plant to the stigma as they searching for nectar in the flower.

It is normal that the ratio of eremophil bee species was low (20\%) in the early spring aspect.

In comparison with the observations of Kratochwil (1988) on P. vulgaris we found mainly social bee species (Apis mellifera, Bombus), while Andrena and Osmia species were the most frequent among solitary species. Andrena bicolor was the most frequent species of the genus in our study as well. We did not collect Lasioglossum lineare, but we found L. fulvicorne, L. laterale and L. xanthopus. Two non-Apoidea Hymenoptera species was collected: Priocnemis mimula and Polistes nimpha.

Our results support the observations of Weryszko-Chmielewska and Sulborska (2011) on Pulsatilla species as Bee-like species were the main pollinators of $P$. grandis.

The studies of Sauberer and Panrok (2015) on Pulsatilla species showed different results from our observations on $P$. grandis. We collected only 1-2 individuals of 4 Halictidae species (L. fulvicorne, L. laterale and L. xanthopus) and the number of individuals of Apis and Bombus species was significantly higher than the number of individuals of the Andrena genus.

Our results meet the observations of Zimmermann (1935), Walker (2011) and Walker and Pinches (2011): Apis mellifera and Bombus species were the most frequent pollinators. However, in our case B. lapidarius was the most frequent species of the genus instead of Bombus terrestris (Zimmermann, 1935).

Compared to the results of Wells and Barling (1971) we collected only 1-2 Bombus pascuorum and Osmia bicolor.

Pulsatilla species produce pollen in early spring when the activity of Aculeata species is starting as well. They attract the insects with a huge amount of pollen and some nectar.

Pulsatilla species have many strategies to ensure the success of allogamy, especially in the case of early flowering species.

As the seed dispersal distances are short the gene flow ensured by pollination plays an important role in the maintenance of the genetic variability of populations. Therefore, the significance of pollinators is high (Hensen et al., 2005).

In our former studies we found significant differences between the number of fruits in the different $P$. grandis populations in the southern part of Bakony Hills (Mészáros T. in prep.) which can indicate the important role of pollinators as well. According to our studies a large number of pollinators have visited the flowers of $P$. grandis. The success of fructification can depend not only on the number of pollinators but on habitat parameters or weather conditions as well. As a consequence, further studies are needed to determine the role of the studied insects in the success of fructification. 


\section{Conclusion}

No special plant-pollinator relation was found between the studied species and its pollinators. This result is not surprising as only $1-2 \%$ of bee species are specialists. Most of the bee species feed on more plant species and most of the plant species are visited by many insects.

The number of bees has decreased considerably in the last decades which can be caused by the changes in landscape structure and the retreat of visited plant species, so the pollination crisis is becoming more obvious (Potts et al., 2010; Biesmeijer et al., 2007). Besides the retreat of food plants the increasing presence of dangerous chemicals reduces the number of pollinators as well (Dainese et al., 2018).

The early flowering of $P$. grandis is very important for bees appearing in early spring as these flowers are the first food sources for them after the pupa stage. In this period of the year only a few plant species produces pollen. After the flowering of $P$. grandis its pollinators (which have longer life cycle than the flowering period of $P$. grandis) visit other plant species occurring in increasing number, so the bees can choose from more food sources. We can speak about mutual dependency as pollinators are necessary for successful fertilization (and with that for the maintenance of genetic diversity of populations), and the flowers $P$. grandis are food sources for early pollinators. Either the decrease of pollinators or early flowering plant populations influences the relation negatively.

With our study we filled the gap of missing information about the pollinators of $P$. grandis and would like to draw attention to the key role of early flowering plant species in the maintenance of bee diversity. In the lack of these species even the non-specialist pollinators can not maintain their populations. Therefore it is important to conserve and maintain the populations of early flowering plant species.

Acknowledgements. We would like to thank Mrs. Józan, Dénes Péteri and Gábor Barad for their help in insect collection. We would like to thank Judit Bódis and István Galambos for their comments on the manuscript. The publication is supported by the EFOP-3.6.3-VEKOP-16-2017-00008 project. The project is co-financed by the European Union and the European Social Fund.

\section{REFERENCES}

[1] Biesmeijer, J. C., Roberts, S. P. M., Reemer, M., Ohlemüller, R., Edwards, M., Peeters, T., Schaffers, A. P., Potts, S. G., Kleukers, R., Thomas, C. D., Settele, J., Kunin, W. E. (2006): Parallel declines in pollinators and insect-pollinated plants in Britain and the Netherlands. - Science 313: 351-354.

[2] Biró, É., Bódis, J., Nagy, T., Tökölyi, J., Molnár, V. A. (2015): Honeybee (Apis mellifera) mediated increased reproductive success of a rare deceptive orchid. - Applied Ecology and Environmental Research 13(1): 181-192. DOI: 10.15666/aeer/1301_181192.

[3] Borhidi, A. (2003): Magyarország növénytársulásai. - Akadémiai Kiadó, Budapest.

[4] Charlesworth, D., Charlesworth, B. (1987): Inbreeding depression and its evolutionary consequences. - Ann Rev Ecol Syst. 18(1): 237-268.

[5] Dainese, M., Riedlinger, V., Holzschuh, A., Kleijn, D., Scheper, J., Steffan-Dewenter, I. (2018): Managing trap- nesting bees as crop pollinators: Spatiotemporal effects of floral resources and antagonists. - J Appl Ecol 2018(55): 195-204. DOI: 10.1111/13652664.12930.

[6] Denisow, B., Wrzesień, M. (2006): The study of blooming and pollen efficiency of Adonis vernalis L. in xerothermic plant communities. - J. Apic. Sci. 50(1): 25-32. 
[7] Denisow, B., Wrzesien, M., Cwener, A. (2014a): Pollination and floral biology of Adonis vernalis L.(Ranunculaceae)-a case study of threatened species. - Acta Societatis Botanicorum Poloniae 83(1): 29-37.

[8] Denisow, B., Strzałkowska-Abramek, M., Bożek, M., Jeżak, A. (2014b): Early spring nectar and pollen and insect visitor behavior in two Corydalis species (Papaveraceae). J. Apic. Sci. 58(1): 93-102.

[9] Denisow, B., Pogroszewska, E., Laskowska, H. (2015): The effect of silicon on nectar and pollen production in Hosta Tratt. 'Krossa Regal'. - Acta Sci. Pol. Hortorum Cultus 14(4): 131-142.

[10] Dostalova, A., Király, G. (2013): Pulsatilla grandis. - The IUCN Red List of Threatened Species 2013: e.T162014A5530433. http://dx.doi.org/10.2305/IUCN.UK.20111.RLTS.T162014A5530433.en.

[11] Du Rand, E. E., et al. (2015): Detoxification mechanisms of honey bees (Apis mellifera) resulting in tolerance of dietary nicotine. - Sci. Rep. 5: 11779. DOI: 10.1038/srep11779.

[12] Dylewska, M. (1987): Die Gattung Andrena Fabricius (Andrenidae, Apoidea) in Nordund Mitteleuropa. - Acta Zoologica Cracoviensa 30/12: 359-708.

[13] Ebmer, A. W. (1970): Die Bienen des Genus Halictus Latr. s. 1. im Grossraum von Linz (Hymenoptera, Apidae) Teil II. - Naturkundliches Jahbuch der Stadt Linz 1970: 19-82.

[14] Ebmer, A. W. (1988): Kritische Liste der nicht-parasitischen Halictidae Österreichs mit Berücksichtigung aller mitteleuropäischen Arten (Insecta: Hymenoptera: Apoidea: Halictidae). - Linzer biologische Beiträge 20/2: 527-711.

[15] Essl, F. (2005): Bestandesentwicklung, Vegetationsanschluss und Gefährdungssituation der Gewöhnlichen Küchenschelle (Pulsatilla vulgaris MILL.) in Österreich von 19912005. - Linzer biologische Beiträge 37(2): 1145-1176.

[16] Gostin, I. N.(2011): Anatomical and micromorphological peculiarities of Adonis vernalis L. (Ranunculaceae). - Pak J Bot 43: 811-820.

[17] Hensen, I., Oberprieler, C., Wesche, K. (2005): Genetic structure, population size, and seed production of Pulsatilla vulgaris (Ranunculaceae) in Central Germany. - Flora 200: 3-14.

[18] Józan, Zs. (1985): A Barcsi borókás fullánkos (Hymenoptera, Aculeata) faunája. - II. Dunántúli Dolgozatok (A) Természettudományi Sorozat 5: 177-192.

[19] Józan, Zs. (1990): A Zselic méhszerü (Hymenoptera), Apoidea faunájának alapvetése. Janus Pannonius Múzeum Évkönyve 34(1989): 81-92.

[20] Józan, Zs. (1992a): A Boronka-melléki Tájvédelmi Körzet fullánkos hártyásszárnyú (Hymenoptera, Aculeata) faunájának alapvetése. - Dunántúli Dolgozatok (A) Természettudományi Sorozat 7: 163-210.

[21] Józan, Zs. (1992b): A Béda-Karapancsa Tájvédelmi Körzet fullánkos hártyásszárnyú (Hymenoptera, Aculeata) faunájának alapvetése. - Dunántúli Dolgozatok (A) Természettudományi Sorozat 6: 219-246.

[22] Józan, Zs. (1995): Adatok a tervezett Duna-Dráva Nemzeti Park fullánkos hártyásszárnyú (Hymenoptera, Aculeata) faunájának ismeretéhez. - Dunántúli Dolgozatok (A) Természettudományi Sorozat 8: 99-115.

[23] Józan, Zs. (1996a): A Mecsek méhszerü faunája (Hymenoptera, Apoidea). - Janus Pannonius Múzeum Évkönyve 40(1995): 29-43.

[24] Józan Zs. (1996b): A Baláta környék fullánkos hártyásszárnyú faunájának (Hymenoptera, Aculeata) alapvetése. - Somogyi Múzeumok Közleményei 12: 271-297.

[25] Józan, Zs. (1998): A Duna-Dráva Nemzeti Park fullánkos hártyásszárnyú (Hymenoptera, Aculeata) faunája. - Dunántúli Dolgozatok (A) Természettudományi Sorozat 9: 291-327.

[26] Józan, Zs. (2000a): A Villányi-hegység fullánkos hártyásszárnyú (Hymenoptera, Aculeata) faunája. - Dunántúli Dolgozatok (A) Természettudományi Sorozat 10: 267 283.

[27] Józan, Zs. (2000b): Külső-Somogy méhszerü (Hymenoptera, Apoidea) faunája. Somogyi Múzeumok Közleményei 14: 307-330. 
[28] Józan, Zs. (2001): Somogy megye fullánkos hártyásszárnyú (Hymenoptera, Aculeata) faunája. - Natura Somogyiensis 1: 269-293.

[29] Józan, Zs. (2002): Az Örség és környéke fullánkos hártyásszárnyú faunájának alapvetése (Hymenoptera, Acuelata). - Praenorica Folia Historico-Naturalia 6: 59-96.

[30] Józan, Zs. (2003): A Látrányi Puszta Természetvédelmi Terület fullánkos hártyásszárnyú (Hymenoptera, Aculeata) faunája. - Natura Somogyiensis 5: 209-233.

[31] Józan, Zs. (2006): A Mecsek fullánkos hártyásszárnyú faunája (Hymenoptera, Acueata). - Folia Comloensis 15: 219-238.

[32] Józan, Zs. (2009): A cserszegtomaji Gyötrös-tető fullánkos hártyásszárnyú (Hymenoptera: Aculeata) faunájának alapvetése. - In: Entomológia: kutatás, szemléletformálás, ismeretterjesztés - Móczár László köszöntése 95. születésnapján. Szegedi Tudományegyetem Ökológiai Tanszéke, Szeged, pp. 119-135.

[33] Józan, Zs. (2014): Adatok Simontornya fullánkos (Hymenoptera, Aculeata) faunájához. In: Szita, É. et al. (eds.) Simontornya ízeltlábúi - In memoriam Pillich Ferenc. - Magyar Biodiverzitás-kutató Társaság, Budapest, pp. 117-129.

[34] Józan, Zs. (2015): A Barcsi borókás fullánkos faunája, III (Hymenoptera: Aculeata). Natura Somogyiensis 26: 95-108.

[35] Józan, Zs. (2016): A balatonfüredi Tamás-hegy fullánkos hártyásszárnyú (Hymenoptera, Aculeata) faunája. - Natura Somogyiensis 30: 47-70.

[36] Józan, Zs. (2017): A Tihanyi Tájvédelmi Körzet fullánkos hártyásszárnyú (Hymenoptera, Aculeata) faunája II. - Folia Musei Historico-Naturalis Bakonyiens is 34: 99-130.

[37] Kaligaric, M., Skornik, S., Ivancic, A., Rebeusek, F., Sternberg, M., Kramberger, B., Sencic, L. (2006): Germination and survival of endangered Pulsatilla grandis (Ranunculaceae) after artificial seeding, as affected by various disturbances. - Israel Journal of Plant Sciences 54: 9-17.

[38] Kratochwil, A. (1988): Zur Bestäubungsstrategie von Pulsatilla vulgaris MILL. - Flora 181: 261-324.

[39] Larson, B. M. H., Barrett, S. C. H.(2000): A comparative analysis of pollen limitation in flowering plants. - Biological Journal of the Linnean Society 69(4): 503-520.

[40] Lindell, T. (1998): Breeding systems and crossing experiments in Anemone patens and in the Anemome pulsatilla group (Ranunculaceae). - Nord. J. Bot. 18: 549-561.

[41] Lowenstein, D. M., Matteson, K. C., Minor, E. S. (2015): Diversity of wild bees supports pollination services in an urbanized landscape. - Oecologia 179: 811. https://doi.org/10.1007/s00442-015-3389-0.

[42] Moquet, L., Mayer, C., Michez, D., Wathelet, B., Jacquemart, A.-L. (2015): Early spring floral foraging resources for pollinators in wet heathlands in Belgium. - Journal of Insect Conservation 9: 1-12. DOI: 10.1007/s10841-015-9802-5.

[43] Móczár, M. (1953): A dongóméhek (Bombus Latr.) faunakatalógusa (Cat. Hym. IV.). Folia Entomologica Hungarica VI/5: 197-228.

[44] Móczár, L. (1956): Pókölődarázs alkatúak - Pompiloidea. - In: Székessy, V. (ed.) Magyarország Állatvilága (Fauna Hungariae) XIII/5. Akadémiai Kiadó, Budapest.

[45] Móczár, M. (1957): Méhfélék - Apidae. - In: Székessy, V. (ed.) Magyarország Állatvilága (Fauna Hungariae) XIII/13. Akadémiai Kiadó, Budapest.

[46] Móczár, M. (1958): Müvészméhek - Megachilidae. - In: Székessy, V. (ed.) Magyaroszág Állatvilága (Fauna Hungariae) XIII/12. Akadémiai Kiadó, Budapest.

[47] Móczár, M. (1967): Karcsúméhek - Halictidae. - In: Székessy, V. (ed.) Magyarország Állatvilága (Fauna Hungariae) XIII/11. Akadémiai Kiadó, Budapest.

[48] Móczár, L., Warncke, K. (1972): Faunenkatalog der Gattung Andrena Fabricius (Cat. Hym. XXVI). - Acta Biologica Szeged 18(1-4): 185-221.

[49] Móczár, L. (1995): Redősszárnyúdarázs szerüek - Vespoidea. - In: Székessy, V. (ed.) Magyarország Állatvilága (Fauna Hungariae) XIII/B/6. Akadémiai Kiadó, Budapest. 
[50] Osborne, J. L., Martin, A. P., Carreck, N. L., Swain, J. L., Knight, M. E., Goulson, D., Hale, R. J., Sanderson, R. A. (2008): Bumblebee flight distances in relation to the forage landscape. -Journal of Animal Ecology 77: 406-415.

[51] Potts, S. G., Biesmeijer, J. C., Kremen, C., Neumann, P., Schweiger, O., Kunin, W. E. (2010): Global pollinator declines: trends, impacts and drivers. - Trends Ecol Evol 25: 345-363.

[52] Randic, M., Brkljacic, A., Lukac, G., Kremer, D. (2013): New localities of rare NATURA 2000 species: Pulsatilla grandis Wender., Genista holopetala (Koch) Bald. and Cypripedium calceolus L. in the NW Dinarides in Croatia. - Natura Croatica 22(1): 95-109.

[53] Sárospataki, M., Novák, I., Molnár, V. (2004): Hazai poszméhfajok (Bombus spp.) veszélyeztetettsége és védelmük szükségessége. - Természetvédelmi Közlemények 11: 299-307.

[54] Sauberer, N., Panrok, A. (2015): Verbreitung und Bestandessituation der Großen Kuhschelle (Pulsatilla grandis) am Alpenostrand in Niederösterreich und Wien. Biodiversität und Naturschutz in Ostösterreich BCBEA 1(2): 262-289.

[55] Schemske, D. W., Husband, B. C., Ruckelshaus, M. H., Goodwillie, C., Parker, I. M., Bishop, J. G. (1994): Evaluating approaches to the conservation of rare and endangered plants. - Ecology 75(3): 584-606.

[56] Schmid-Egger, C., Scheuchl, E. (1997): Illustrierte Bestimmungstabellen der Wildbienen Deutschlands und Österreichs, Band III: Andrenidae. - Eigenverlag, Velden/Vils.

[57] Schmiedeknecht, O. (1930): Hymenopteren Nord- und Mitteleuropas, mit Einschluss von England, Südschweiz, Südtirol und Ungarn. - Verlag von Gustav Fischer, Jena.

[58] Steffan-Dewenter, I., Kuhn, A. (2003): Honeybee foraging in differentially structured landscapes. - Proceedings of the Royal Society of London Series B-Biological Sciences 270: 569-575.

[59] Strzałkowska-Abramek, M., Jachuła, J., Dmitruk, M., Pogroszewska, E. (2016): Flowering phenology and pollen production of three early spring Pulsatilla species. Acta Sci. Pol. Hortorum Cultus 15(6): 333-346.

[60] Walker, K. (2011): Pulsatilla vulgaris (L.) Mill. https://www.scribd.com/document/296701252/Pulsatilla-vulgaris-PlantlifedossierFINAL-Apr11-pdf (downloaded 25.03.2018).

[61] Walker, K. J., Pinches, C. E. (2011): Reduced grazing and the decline of Pulsatilla vulgaris Mill. (Ranunculaceae) in England, UK. - Biological Conservation 144: 30983105.

[62] Walther-Hellwig, K. and Frankl, R. (2000): Foraging habitats and foraging distances of bumblebees, Bombus spp. (Hym., Apidae), in an agricultural landscape. - J. Appl. Entomol. 124: 299-306.

[63] Wells, T. C. E., and Barling, D. M. (1971): Biological Flora of the British Isles. Pulsatilla vulgaris Mill. (Anemone Pulsatilla L.) - The Journal of Ecology 59(1): 275-292.

[64] Weryszko-Chmielewska, E. and Sulborska, A. (2011): Staminodial nectary structure in two Pulsatilla (L.) species. - Acta Biologica Cracoviensia Series Botanica 53(2): 94-103.

[65] Wolf, H. (1972): Pompilidae - In: Sauter, W. (ed.): Insecta Helvetica, Fauna 5. Hymenoptera. Entomologische Gesellschaft, Zürich, pp. 1-176.

[66] Zimmermann, W. (1935): Genetische Untersuchungen an Pulsatilla I-III. - Flora oder Allgemeine Botanische Zeitung 129(2): 158-234. 